\title{
Study on the Influence of Local Colleges and Universities on the Soft Power of Urban Culture and Effective Ways
}

\author{
Huanquan Shen, Xiaobo Yu, Yuqing Liang, Dandan Liu* \\ Qiqihar Medical University, Qiqihar, Heilongjiang Province, China \\ *Corresponding author: Dandan Liu
}

Keywords: local colleges and universities; regional culture; soft power.

\begin{abstract}
The soft power of urban culture is the inner motive of a city which helps the city to establish its unique competitive advantages and maintain sustainable development. In the era of knowledge economy, local colleges and universities serve as the carrier and innovator of urban culture, and have positive impacts in promoting the development of the soft power of urban culture and the revitalization of the city. At the same time, the upgrade of cultural soft power also influences local colleges and universities through various ways, and promotes the construction and development of these colleges and universities.
\end{abstract}

\section{Introduction}

Local colleges and universities are rooted in local regions, and develop together with the construction of local culture; they have distinct and prominent local features. University and college culture interact with regional and local culture to coordinate the development. Regional culture enriches and nourishes the culture of local colleges and universities, while local colleges and universities inherit, lead and spread the local and regional culture. In cities with strong cultural influence, local universities serve as the supporting role. Through cultural cultivation, innovation, dissemination and exchanges, universities and colleges can greatly enhance the taste of local region, promote the sustainable development of local economy and enhance the comprehensive competitiveness of local areas. In a word, university culture and local culture complement with each other; the city helps to build the cultural atmosphere of universities, while universities and colleges provide city culture with strong vitality.

\section{The Definition of Soft Power of Urban Culture}

With the development of the times, the construction and development level of a city is not only determined by its "hard power" like economy development and infrastructure construction. The city development concept has transformed its focus from hard power development to soft power construction. The concept of "Soft Power" was proposed by Joseph Nye, a global strategy research expert in 1990s. Joseph Nye holds that the power of a country does not only include its hard power like resources power, economic power, military power and technological power, but also includes its soft power in ideology, value concept, culture influence and foreign policy. With strong soft power, a country can "achieve the ideal results through attraction rather than force, convince others to follow it or let them follow the standard or system it makes, and to act according to its ideas." This opinion has attracted the attention from a lot of western scholars, who has paid attention to the usage of soft power in enhancing the comprehensive national strength and core competitiveness. The so-called "city cultural soft power" means the overall cultural connotation embodied by the city during its development and construction process. City cultural soft power covers intangible aspects of city development, and is a kind of special strength which reflects the influence of this city through cohesion, charisma, innovation ability and coordination ability. The construction of economy, public service, ecological environment, infrastructure and other aspects forms the city's hard power, which 
serves as the muscles and bones of a modern civilized city; while its cultural quality and humanistic environment form the city's soft power, which serves as the soul and spirit of the city.

\section{The Significance of Improving Soft Power of City Culture}

The soft power of urban culture is an important part of the comprehensive competitiveness of cities. It provides spirit supports for cities; it is an important manifestation of urban appearance from the perspective of enhancing the cities' comprehensive strength and competitiveness. The promotion of cultural soft power is conducive to enhancing the core competitiveness of cities, promoting urban cohesion, promoting urban economic growth and expanding urban influence. Every city or region needs culture as a booster. Only when local authorities attach importance to material construction and cultural construction at the same time, can these areas develop and grow in the new era, and finally achieve their own prosperity and vitality. In this sense, the level of cultural soft power has direct impacts on the strength of the core competitiveness of cities. In order to become a competitive city, local authorities must promote the construction of its own cultural soft power quickly. Only strong cultural soft power can provide cities with endless source of power in the increasingly fierce urban competition, so as to continuously enhance their innovation vitality and popularity, and to share more investment capitals and unlimited business opportunities in the future.

\section{Major Problems in Improving Regional Cultural Soft Power Through Local Colleges and Universities}

With the proposal of "cultural soft power" concept, cities all over the country start to build "strong cultural cities", in order to establish city name card and city brand, transform cultural resources to real wealth, and promote the development of the real economy. To achieve this goal, we need to dig and develop urban culture deeply. But the goal of "developing cities through culture construction" cannot be achieved by the backward urban culture alone. As the gathering place of modern civilization and advanced culture, colleges and universities must take their responsibilities on cultural construction. They need to actively explore their potentials in city cultural construction, use their powerful propaganda functions to promote culture communication, and give full play to their important roles in the promotion of cultural soft power. These approaches are not only the focuses of strengthening college culture, but also important ways to enhance regional cultural soft power. However, there are some problems in the interaction between local universities and colleges and the city of Qiqihar.

The multi-objective goal of urban development is not obvious. Economy is the only focus. This does not conform to the connotation of urban development. Local colleges and universities are not mobilized enough to study the resources of cultural connotations; further studies, excavation, arrangement and development of cultural history, regional characteristics and city resources are still needed. The three parties of the government, enterprises and schools are not correctly positioned, and they fail to fully understand the importance of their existence and mutual interaction. Maneuverability measures are not enough. Understandings on its own position and functions are not deep enough. During the process of their own development, they all meet problems on capital, talent, technology, management and development modes. But they do not coordinate with each other and form a complete whole.

\section{Solutions to Existing Problems}

\subsection{Promoting cultural research and urban construction.}

Local universities and colleges are important places in carrying out cultural dissemination and innovative researches, and promoting the spirit of the times. They undertake the lofty mission of educating and guiding the successors of socialist culture, but they also need to be rooted in regional cultures. Local universities and colleges should actively probe, study and promote city culture, and serve the development of region economy as well as culture construction. Local colleges and 
universities can gather talents, and they should rely on this advantage to play the role of talent banks. Local government, colleges and universities should take a variety of ways to guide and encourage experts and scholars to study and refine the spirits of regional culture. On the basis of research projects at all levels, in-depth exploration of regional culture and traditional culture should be carried out to publicize the spirit of the city and the times. Colleges and universities also need to introduce social resources, integrate research efforts, organize research teams, pay attention to regional cultural resources, and carry out in-depth researches on the theory and practice of constructing local spiritual civilization through taking their professional advantages of comprehensive universities. Research centers based on cultural characteristics of the region should be established to research, explore, consolidate and develop the history, culture, geographical features and resources situation of the city in-depth, in order to guide the development direction of spiritual civilization, and provide support for local governments on decision-making. At the same time, scientific research institutions in universities should also rely on their own research advantages, provide technical guidance for local enterprises in production, and contribute to the development of local economy.

\subsection{Promoting cultural publicity and expanding influences of the city.}

First of all, colleges and universities can use a variety of educational methods to bring research results into the classroom and teach students about urban culture. Once students remember information about urban culture, the influences of urban culture will be enhanced through the radiation effects of graduates. Secondly, school authorities should make use of the advantages of professional talents and their innovative ideas, and cooperate with other schools to create literary and artistic products, as well as the business card of the city. They need to cooperate with cultural media companies, in order to promote cultural propaganda through film, television, entertainment, publishing and other forms. They can also provide professional consultants and training programs for the construction of enterprise culture, establish demonstration area of elegant folk culture, and display the culture and history of the city through stage show and show tour. By means of all kinds of theatrical performances and artistic skills, the influences of the city can be expanded. At the same time, college students can also set up innovation experiment base relying on the "Internet plus" innovation mode. Students should be guided to explore, research and develop city culture with their professional knowledge. Art crafts of city culture, as well as distinctive tourism souvenirs should be designed and produced; city culture propaganda films should also be produced and publicized to provide strong support and protection for the development of regional cultural industry.

\subsection{Promoting cultural communication and improving the comprehensive quality of the city.}

The resources of colleges and universities are rich, rigorous, scientific and standardized. These resources in colleges and universities can greatly improve the overall quality of urban residents and enrich the cultural life of the majority of citizens. Universities can open part of their teaching resources to the public, and establish scientific bases to educate citizens, as well as primary and middle school students, in order to enhance the cultural level of the whole city. Medical schools can organize medical lectures regularly to publicize healthy lifestyle. These lectures will not only improve the life quality of citizens, but also reduce the incidence of common disease and save a lot of medical resources, so as to enhance the happiness index of residents. Art school students can plan and participate into performances to enrich the cultural life of citizens, and thus change the overall cultural level of the general public, and fundamentally improve the cultural soft power of the city. These activities are beneficial to the promotion of local culture construction and innovation, and have positive impacts in enhancing the local cultural soft power. Meanwhile, we should also actively explore the potential effects of higher learning institutions in the construction of city culture. The powerful functions of colleges and universities in cultural transmission should also be fully used to promote the construction of cultural soft power.

To sum up, in the process of enhancing the cultural soft power of cities, local governments can unite themselves with local universities and colleges, make full use of higher learning institutions' resource advantages, actively explore urban cultural history and regional characteristics, create cultural brands, and expand urban influences. Universities need to be actively involved in city 
construction, use their own advantages on professional talents and resources to promote cultural communication and cultural heritage protection, and combine city cultural characteristics and cultural landscapes with the connotation of the new times, in order to further enhance the cultural soft power of cities. As the gathering place of talents and knowledge, local universities and colleges must take the initiative to integrate into regional economic and social development, and actively serve the development of local society and regional economy. Researches and practices on modes of strengthening soft power of city culture through local colleges and universities should be carried out, so as to improve the consciousness and ability of higher education institutions to participate in the construction of cultural soft power. It is not only the requirement of a city to implement its strategy of "building the city with strong cultural influences" and promote cultural development, but also the requirement of local colleges and universities to realize their functions on cultural heritage and innovation, and achieve their own values.

\section{Acknowledgement}

Fund Project: This paper is supported by Foundation for Planning Projects on Science and Technology of Qiqihar. (Project No.: RKX-201307).

\section{References}

[1] G. Feng, Strengthening cultural construction of colleges and universities to enhance national cultural soft power, J. Hunan Social Sciences. 5 (2011) 193-194.

[2] X.L. Zhang, Q. Sun, Taking advantages of local colleges and universities and promoting the construction of soft power of urban culture, J. Journal of Daqing Normal University. 34 (2014) 144-145. 